\title{
USKLAĐIVANJE ZAKONODAVNOG SISTEMA REPUBLIKE SRBIJE SA PRAVOM EVROPSKE UNIJE U OBLASTI CIVILNOG VAZDUHOPLOVSTVA
}

\begin{abstract}
Irena ARSIĆ BOGDANOVIĆ*
Apstrakt: Pojmovi „približavanje“ i „usklađivanje“ nacionalnih pravnih sistema pažljivo su korišćeni od samog početka stvaranja Zajednice. Termin usklađivanje (harmonizacija) predstavlja neophodan preduslov za ujednačavanje pravnih sistema različitih država na najvišem mogućem nivou. Razlog za ujednačavanje pravnih sistema leži u bazičnoj potrebi za uspostavljanjem odnosno funkcionisanjem zajedničkog tržišta, što predstavlja jedan od nosećih stubova Zajednice. Pravni osnov usklađivanja za države članice Evropske unije može se tražiti u odredbama članova 3(ž) i 94 Ugovora o osnivanju Evropske zajednice. Nakon što je uspostavljeno jedinstveno evropsko vazduhoplovno tržište i nakon ekspanzije vazdušnog saobraćaja na liberalizovanom tržištu, EU je razvila spoljnu vazduhoplovnu politiku koja se zasniva na pridruživanju trećih zemalja Zajedničkom evropskom vazduhoplovnom području (Eurpoean Common Aviation Area (u daljem tekstu ECAA)) uz uslov da se nacionalni zakonodavni sistemi usklade sa propisima EU. Za Republiku Srbiju, koja nije članica EU, usklađivanje nacionalnih propisa sa pravom EU je deo sveopšte strategije za pridruživanje i pristupanje EU. Sporazum o stabilizaciji i pridruživanju stupio je na snagu 1. septembra 2013, čime je Srbija dobila status države pridružene EU, pri čemu je transportna politika i usklađivanje vazduhoplovnih zakona sa pravnom tekovinom EU predviđeno pregovaračkim poglavljem 14. Dve najvažnije obaveze koje je naša zemlja preuzela jesu uspostavljanje zone slobodne trgovine i usklađivanje zakonodavstva sa pravom EU. Proces usklađivanja zakonodavnog sistema Srbije sa pravom EU u oblasti civilnog vazduhoplovstva odvija se skoro punih 15 godina kroz proces pristupanja ECAA. Ostaje otvoreno pitanje da li će napori za usklađivanje svih aspekata obavljanja vazdušnog saobraćaja doneti ekonomske i društvene koristi i Srbiji.

Ključne reči: Jedinstveno evropsko vazduhoplovno tržište, Zajedničko evropsko vazduhoplovno područje, Sporazum o ECAA, Liberalizacija vazdušnog saobraćaja, Usklađivanje zakonodavnog sistema sa pravom EU, Implementacija evropskih propisa, sadržanih u Aneksu I ECAA.
\end{abstract}

\footnotetext{
* Supervizor podrške za predstavništva u inostranstvu u Air SERBIA.

E-mail: irenararsic@yahoo.com.
} 


\section{1) UVOD}

Vazduhoplovstvo Evropske zajednice (EZ) bilo je izvan glavnog toka evropskih integracija skoro pune tri decenije od potpisivanja Rimskog ugovora. Vlade evropskih država su u potpunosti regulisale vazdušni saobraćaj koji se obavljao na osnovu bilateralnih sporazuma. Preokret u regulisanju civilnog vazduhoplovstva na evropskom tržištu dogodio se tek nakon više presuda Evropskog suda pravde (sada Suda pravde EU) i usvajanja Jedinstvenog evropskog akta $1986 .{ }^{1}$

Evropska unija (U daljem tekstu: EU) od 1987. postepeno je razvijala sveobuhvatan regulatorni okvir za vazdušni transport kroz tri uzastpone faze ili paketa mera za liberalizaciju vazdušnog saobraćaja EU. Usvajanjem trećeg paketa mera, ${ }^{2}$ Savet je dovršio proces stvaranja Jedinstvenog evropskog vazduhoplovnog tržišta i tako ispunio zahtev Jedinstvenog evropskog akta za uspostavljanjem jedinstvenog unutrašnjeg tržišta do kraja $1992 .{ }^{3}$

Komisija je bila najuporniji organ EU/EZ u nastojanju da se unificira politika prevoza, i preuzela je brojne korake za uspostavljanje nadležnosti za upravljanje spoljnim odnosima u domenu vazduhoplovstva. Nadležnost Komisije za saradnju sa spoljnim stranama potvrdio je Evropski sud pravde (ESP) u odluci o slučajevima otvorenog neba od 5. novembra 2002. ${ }^{4}$ Ubrzo zatim, Komisija je definisala plan za razvoj spoljne vazduhoplovne politike Zajednice ${ }^{5}$ predviđajući tri osnovna pravca delovanja: usklađivanje postojećih bilateralnih ugovora o avio-uslugama sa zakonima Zajednice, stvaranje zajedničkog vazduhoplovnog područja sa susednim zemaljama kroz sporazume koji predviđaju usvajanje propisa o vazdušnom saobraćaju Zajednice i zaključivanje ugovora o vazdušnom saobraćaju sa ključnim strateškim partnerima. Važan novi koncept koji se pojavio jeste koncept usaglašavanja različitih zakonodavnih režima zemalja nečlanica sa pravnom tekovinom EU, kroz pristupanje trećih zemalja Sporazumu o uspostavljanju Zajedničkog evropskog vazduhoplovnog područja (eng. European Common Aviation Area Agreement, u daljem tekstu: Sporazum o ECAA).

Republika Srbija potpisala je Sporazum o ECAA 29. juna 2006. sa EU, zemljama Zapadnog Balkana, Islandom i Norveškom, a Narodna skupština Srbije ga je

\footnotetext{
${ }^{1}$ Case 167-73, Joined Cases 209 to 213/84, Joined Cases 209 to 213/84, Joined Cases 209 to 213/84.

${ }^{2}$ Treći paket: Uredba Saveta br. 2407/92/E3, Uredba Saveta br. 2408/92/E3, Uredba Saveta br. 2409/92/EE3, Uredba Saveta br. 2410/92/EE3 i Uredba Saveta br. 3875/87/EE3.

${ }^{3}$ Jedinstveni evropski akt, član 13, OJ L 169/1.

${ }^{4}$ „Saopštenje Komisije o posledicama Odluke Suda od 5. novembra 2002. godine na evropsku politiku vazdušnog transporta", COM(2002)0649, 19.11.2002.

${ }^{5}$ Saopštenje Komisije - Razvoj agende za spoljnu vazduhoplovnu politiku Zajednice 1(2), COM (2005) 79 final 11.03.2005.
} 
ratifikovala 13. maja 2009. ${ }^{6}$ Primena Sporazuma je jedan od uslova za ulazak Srbije u EU. ${ }^{7}$ Od potpisivanja Sporazuma do danas Srbija je izvršila značajne izmene svog zakonodavnog okvira u cilju usklađivanja sa pravnom tekovinom EU u domenu vazduhoplovstva. Međutim, proces pristupanja ECAA još uvek je u prvoj tranzicionoj fazi. Nema jasnih razloga kojima bi mogao da se objasni ovako usporen proces pridruživanja, pogotovo imajući u vidu obavezu da se u domaće zakonodavstvo implementiraju zakoni i pravila EU u procesu evrointegracija.

Ovaj rad istražuje i analizira razvoj zakonskih okvira na osnovu kojih je stvoren konsolidovani vazduhoplovni pravni poredak u Evropi, kao i uticaj spoljne vazduhoplovne politike EU na zakonodavni okvir Srbije, a time i na poslovanje nacionalne avio-kompanije i ekonomski i društveni život lokalnog stanovništva.

\section{2) USPOSTAVLJANJE JEDINSTVENOG TRŽIŠTA VAZDUŠNOG PREVOZA U EVROPI}

Rimski ugovor iz 1957. povezao je države Zapadne Evrope u cilju stvaranja ekonomski efikasnog unutrašnjeg tržišta Zajednice. Zato su autori nacrta Rimskog ugovora predvideli uspostavljanje zajedničke politike prevoza, zabranili aktivnosti usmerene protiv konkurencije, zabranili davanje državne pomoći kompanijama ukoliko takva pomoć nije u skladu sa izvesnim odredbama o izuzeću, i predvideli implementaciju zajedničke politike prevoza. Međutim, nije bilo jasno definisano da li avio-prevoz podleže opštim odredbama Ugovora, niti su bile jasno definisane nadležnosti Saveta i Komisije za regulisanje vazdušnog prevoza. ${ }^{8}$ Usled nedostatka određenog jezika u Rimskom ugovoru, ${ }^{9}$ Savet ostaje neaktivan po pitanju ostvarivanja zajedničke politike prevoza predviđene članovima 3 (stav e), 61, 74, 75 i 84, sve dok ESP nije potvrdio nadležnost Komisije i Saveta za regulisanje vazdušnog prevoza. ${ }^{10}$

\footnotetext{
${ }^{6}$ Zakon o potvrđivanju Multilateralnog sporazuma između Evropske zajednice i njenih država članica, Republike Albanije, Bosne i Hercegovine, Republike Bugarske, Republike Hrvatske, Bivše Jugoslovenske Republike Makedonije, Republike Island, Republike Crne Gore, Kraljevine Norveške, Rumunije, Republike Srbije i Misije privremene uprave Ujedinjenih nacija na Kosovu (u skladu sa Rezolucijom Saveta bezbednosti UN 1244 od 10. juna 1999) o uspostavljanju zajedničkog evropskog vazduhoplovnog područja, Službeni glasnik RS - Međunarodni ugovori, broj 38/2009-94 od 25. maja 2009. godine.

${ }^{7}$ Sporazum o ECAA, sajt Ministarstva za evropske integracije RS, dostupno na https://www.mei. gov.rs/srp/dokumenta/sporazumi-sa-eu/sporazum-o-otvorenom-nebu, (pristupljeno: 7.12. 2020).

${ }^{8}$ Sporazum o osnivanju Evropske zajednice, kako je dopunjen kasnijim sporazumima, Rim 25. mart 1957. godine, članovi 85 i 86.

${ }^{9}$ Ibid., članovi 61, 74, 75 i 84.

${ }^{10}$ Case 167-73, Joined Cases 209 to 213/84, Joined Cases 209 to 213/84, Joined Cases 209 to $213 / 84$.
} 
Pored presuda ESP koje su postale temelj za regulisanje civilnog vazduhoplovstva u Evropi, veliki značaj za uspostavljanje zakonskog okvira za regulisanje vazdušnog saobraćaja na nivou Zajednice imao je i Jedinstveni evropski akt iz 1986. Ovim Aktom promenjena je odredba o jednoglasnom glasanju i time omogućeno Savetu da odlučno sprovodi propise o konkurenciji i umanji uticaj državne moći na civilno vazduhoplovstvo Zajednice, bez suočavanja sa vetom od strane bilo koje pojedinačne države članice. ${ }^{11}$ Nakon usvajanja Jedinstvenog evropskog akta, EU je postepeno razvila sveobuhvatni zakonodavni okvir za regulisanje civilnog vazduhoplovstva EU putem tri različita paketa mera za liberalizaciju vazdušnog prevoza.

Prvim paketom bile su ukinute odredbe o jednom povlašćenom prevozniku, ublaženi zahtevi za podelu kapaciteta i za nadzor državnih vlasti nad određivanjem cena prevoza. ${ }^{12}$ Drugi paket je otvorio rute između skoro svih aerodroma Zajednice i relaksirao ograničenja u vezi sa uslugama pete slobode i imenovanjem više avioprevoznika za saobraćaj na pojedinim rutama. ${ }^{13}$ Trećim paketom uklonjena su sva preostala komercijalna ograničenja za evropske avio-kompanije koje posluju unutar EU. ${ }^{14}$ Osnovni princip liberalizacije jeste da bilo koji vazdušni prevoznik Zajednice može slobodno da određuje cene za putnike i teret i da ima slobodan pristup bilo kojoj ruti unutar EU.

Proces liberalizacije vazduhoplovnog tržišta Zajednice završen je tako što je trećim paketom mera za liberalizaciju, pa kasnije Uredbom br. 1008/2008 kojom su zamenjene Uredbe br. 2407/92, 2408/92 i 2409/92 u objedinjenom obliku, ${ }^{15}$ stvoreno jedinstveno vazduhoplovno tržište EU, a nacionalni prevoznici država članica postali prevoznici Zajednice. ${ }^{16}$ Svi ovi propisi primenljivi su isključivo na saobraćaj unutar EU, dok saobraćaj izvan EU ostaje regulisan bilateralnim ugovorima potpisanim između država članica i trećih zemalja. Zbog toga, težnja EU je da se ECAA proširi i na države koje nisu u EU uz uslov usaglašavanja zakonodavstava trećih zemalja sa vazduhoplovnom pravnom tekovinom EU. ${ }^{17}$

\footnotetext{
${ }^{11}$ Jedinstveni evropski akt, član 16, stav 5, OJ L 169/1.

${ }^{12}$ Prvi paket: Uredbe Saveta br. 3975/87/EE3 i br. 3976/87/EE3; Direktiva Saveta 87/601/EE3 i Odluka Saveta 87/602/EE3.

${ }^{13}$ Drugi paket: Uredbe Saveta br. 2342/90/EE3, 2343/90/EE3 i br. 2344/90/EZ.

${ }^{14}$ Treći paket: Uredbe Saveta br. 2407/92/E3, br. 2408/92/E3, br. 2409/92/EE3, br. 2410/92/EE3 u br. 2411/92/EEZ.

15 „Uredba br. 1008/2008 Evropskog parlamenta i saveta od 24. septembra 2008. o opštim pravilima za obavljanje usluga vazdušnog saobraćaja", OJ L, 293/3, 31.10.2008.

16 "Air transport: market rules", European Parliament, https://www.europarl.europa.eu/ factsheets/en/sheet/131/luftverkehr-marktregelungen, pristupljeno: 7.12.2020.

17 „Razvoj agende za spoljnu vazduhoplovnu politiku Zajednice”, Saopštenje Komisije 1(2), COM (2005) 79 final 11.03.2005), član 2.
} 


\section{3) POLITIKA EU PREMA DRŽAVAMA NEČLANICAMA}

U saopštenju koje je dala Komisija tri godine nakon usvajanja trećeg paketa mera navedeno je da je proces liberalizacije doneo značajne pozitivne rezultate: otvorene su nove rute, omogućene nove usluge, pospešena je konkurencija, pao je tržišni udeo dominantnih nacionalnih prevoznika i formiraju se savezništva i partnerstva. ${ }^{18}$ Sa druge strane, stav Komisije je bio da slaba tačka unutrašnjeg tržišta EU ostaje pitanje nepotpunih odnosa koji su i dalje predmet bilateralnih sporazuma između država članica i zemalja nečlanica. Komisija je navela da zbog različitosti ovih sporazuma, države članice i njihovi avio-prevoznici moraju da rade u neusklađenim sistemima zbog propisa država nečlanica koji su nekompatibilni ili nespojivi sa unutrašnjim tržištem EU. ${ }^{19}$

Komisija je smatrala neprihvatljivim da države članice grade svoje odnose sa trećim zemljama potpisivanjem bilateralnih ugovora u vazduhoplovnom sektoru. Ne odustajući od ovog stava, Komisija je od 11. marta 1998. vodila sudske sporove pred ESP protiv osam država članica koje su potpisale bilateralne ugovore o otvorenom nebu sa SAD. ${ }^{20}$

ESP je doneo odluku 5. novembra 2002. o slučajevima otvorenog neba, koja je predstavljala polaznu tačku za izmenu tada važećih ugovora o međunarodnim uslugama. Neposredno nakon toga Komisija je izdala dva zvanična saopštenja. U prvom saopštenju, ${ }^{21}$ Komisija je tražila da se Savet saglasi sa mandatom Komisije za vođenje pregovora o zameni postojećih bilateralnih ugovora između SAD i zemalja članica, ugovorom koji će biti na nivou Unije. U drugom zvaničnom saopštenju koje je Komisija izdala 2003, u vezi sa odnosima između EU i trećih zemalja u oblasti vazdušnog prevoza, Komisija je obrazložila na koji način namerava da vodi spoljne odnose u domenu vazduhoplovstva. ${ }^{22}$

Savet EU je 5. juna 2003. dao dvostruki mandat Komisiji: da otpočne pregovore sa SAD o otvorenom vazduhoplovnom području, i da počne pregovore sa trećim zemljama u vezi sa izmenama "klauzule o državljanstvu“ iz važećih ugovora. ${ }^{23} \mathrm{U}$

\footnotetext{
${ }^{18}$ „Saopštenje Komisije Saveta i Evropskog Parlamenta o uticaju trećeg paketa mera za liberalizaciju vazdušnog prevoza", COM (96) 514 final, 22.10.1996, I-IV.

${ }^{19}$ Ibid., p. 5.

${ }^{20}$ Početkom XX veka, države članice EU potpisale su više ugovora sa SAD o otvorenom nebu. SAD su potpisale prvi sporazum o otovorenom nebu sa Holandijom u oktobru 1992, a zatim i sa drugim evropskim zemljama, uključujući: Austriju, Češku, Belgiju, Dansku, Finsku, Nemačku, Luksemburg, Norvešku, Švedsku, Švajcarsku i Island.

${ }^{21}$ „Saopštenje Komisije o posledicama Odluke Saveta od 5. novembra 2002. na evropsku politiku vazdušnog transporta", COM(2002)0649, 19.11.2002.

22 „Saopštenje Komisije o odnosima između Zajednice i trećih zemalja u oblasti vazdušnog transporta", COM/2003/94 final.

${ }^{23}$ Ibid., stav 45.
} 
decembru 2004. Savet je ovlastio Komisiju da otpočne pregovore sa osam zemalja Jugoistočne Evrope o Sporazumu o ECAA, s ciljem da se susedne države na jugoistoku Evrope integrišu u unutrašnje vazduhoplovno tržište EU uz otvaranje pristupa tržištu i potpunu primenu vazduhoplovnog prava EU. ${ }^{24}$

EU je ubrzo postala vodeća sila i poštovani kreator politike u oblasti vazdušnog transporta. S obzirom na opsežan zakonodavni okvir EU, koji uključuje brojne uredbe i direktive koje su na snazi od 1988, avio-kompanije država koje nisu članice EU sve više su pod uticajem vazduhoplovne pravne tekovine EU. ${ }^{25}$

\section{4) PRIDRUŽIVANJE REPUBLIKE SRBIJE ECAA}

Težnja Srbije na samom početku XXI veka bila je da bude prepoznata kao potencijalni kandidat za članstvo u EU i da se uspostavi režim vizne liberalizacije koji bi omogućio građanima Srbije da putuju unutar šengenskog prostora, ${ }^{26}$ dok je vazduhoplovni sektor vodio borbu za oporavak nacionalne avio-kompanije od pada tokom poslednjih deset godina. ${ }^{27}$ Nacionalna avio-kompanija bila je suočena sa dugovima, sudskim sporovima, manjkom stalnog i obrtnog kapitala i sumnjama u opstanak poslovanja. ${ }^{28}$ Najveći aerodrom na Zapadnom Balkanu i dalje je bio u Beogradu, mada je spadao u male aerodrome prema tadašnjim kriterijumima, sa dva (2) i 1.6 miliona putnika u 2005. ${ }^{29}$ Pored jake konkurencije na sada liberalizovanom Evropskom tržištu, nacionalni prevoznik Srbije dobio je i nove

24 „Politika vazdušnog prevoza Zajednice prema susednim zemljama”, Saopštenje Komisije, COM/2004/0074 final, 09.02.2004.

${ }^{25}$ Richard Smithies, "Regulatory Convergence - Extending the Reach of EU Aviation Law", Journal of Air Law and Commerce, Vol. 72/3, 2007.

${ }^{26}$ Zvanična veb-stranica Evropske unije, Srbija i EU, dostupno na https://eeas.europa. eu/headquarters/headquarters-homepage/27547/serbia-and-eu_en, pristupljeno: 22.12. 2020.

${ }^{27}$ Svetski razvoj nacionalne avio-kompanije JAT, bio je zaustavljen uvođenjem ekonomskih sankcija Jugoslaviji 30. maja 1992. na osnovu Rezolucije br. 757 Saveta bezbednosti UN 23. septembra 1994. godine. Savet bezbednosti UN usvojio je Rezoluciju 943 kojom su sankcije delimično suspendovane. Može se smatrati da su sankcije u potpunosti ukinute JAT-u 1. marta 1997. kada je kompanija ponovo primljena u Klirinšku kuću, bez koje su finansijske transakcije među avio-kompanijama praktično nemoguće.

28 "Jat Airways" Belgrade, A Joint Stock Company for Air Traffic, Financial Statements As of and For the Year Ended 31 December 2008, Independent Auditor's Report, BDO, p. 6.

29 "The European Common Aviation Area and the Western Balkans: Domestic Reforms and Regional Integration in Air Transport", Office for South East Europe, European Commission World Bank, February 2007, p. 3. 
konkurente u regionu, s obzirom na to da su bivše jugoslovenske republike osnovale svoje nacionalne avio-kompanije. ${ }^{30}$

Sa druge strane, tržište usluga vazdušnog prevoza u Evropi doživljavalo je ekspanziju kao rezultat liberalizacije. Struktura vazduhoplovnog tržišta bila je znatno promenjena. Države članice više nisu regulisale poslovanje avio-kompanija, na tržište su ušli novi avio-prevoznici, povećan je nivo konkurencije, kreirani su novi poslovni modeli. Niskotarifni prevoznici izvršili su snažan uticaj u smislu cene prevoza, nivoa konkurencije, ukupnih prinosa, prostorne dekoncentracije saobraćaja i razvoja saobraćaja na malim aerodromima EU. ${ }^{31}$

Rešenje za opstanak vazduhoplovnog sektora Srbija je videla u pridruživanju ECAA, uz usklađivanje prava i standarda za poslovanje u vazduhoplovstvu sa regulativama EU, kao i u privatizaciji i restrukturiranju nacionalnog avioprevoznika. ${ }^{32}$ Započeta je intenzivna saradnja između Srbije i Evropske komisije u oblasti vazduhoplovstva koja se odvija na bilateralnom i multilateralnom nivou. ${ }^{33}$

Sredinom 2005, Evropska komisija je dala predlog za odluku Saveta o potpisivanju i privremenoj primeni Sporazuma između Evropske zajednice i Srbije i Crne Gore (SCG) o izvesnim aspektima avio-usluga. ${ }^{34} \mathrm{U}$ Predlogu je bilo navedeno da se međunarodni vazdušni saobraćaj između država članica i SCG tradicionalno uređivao bilateralnim sporazumima koji su sadržali odredbe o imenovanju prevoznika odnosnih država, a koje su bile u suprotnosti sa zakonom EU. Kako je bilo istaknuto u Predlogu, ovakve odredbe predstavljale su diskriminaciju prevoznika Zajednice budući da je članom 43 Ugovora o osnivanju zajednice zabranjeno ograničavanje slobode osnivanja državljanima države članice na teritoriji druge države članice. ${ }^{35}$

\footnotetext{
${ }^{30}$ Croatia airlines, osnovana 20.08.1989; Montenegro airlines, osnovana 25.10.1994; Makedonski avio-transport (MAT) 1994-2009; Air Srpska 1998-2003; Air Bosna/B\&H airlines, 1994-2015; Albanian airlines 1991-2011.

${ }^{31}$ Guillaume Burghouwt, Airline Network Development in Europe and its Implications for Airport Planning, Ashgate Publishing, Ltd. (2007), pp. 12-26.

32 "Jat Airways" Belgrade, A Joint Stock Company for Air Traffic, Financial Statements As of and For the Year Ended 31 December 2008, Independent Auditor's Report, BDO, p. 6.

${ }^{33}$ Međunarodna saradnja i evropske integracije, DCV, dostupno na: http://www.cad.gov.rs/ strana/19851, pristupljeno, 22.12.2020.

34 "Proposal for a Council Decision on the signature and provisional application of the Agreement between the European Community and Serbia and Montenegro on certain aspects of air services", Commission of the European Communities, Brussels, 29.07.2005. COM (2005) 353 final.

35 „Sporazum o osnivanju Evropske zajednice”, član 43, (konsolidovana verzija 2002).
} 
Shodno navedenom, potpisan je Sporazum između (SCG) i EZ o određenim aspektima vazdušnih usluga (tzv. Horizontalni sporazum) tokom 2005, ${ }^{36}$ kojim su izmenjene određene odredbe postojećih bilateralnih sporazuma o vazdušnim uslugama. Zamenjene su tradicionalne klauzule o imenovanju prevoznika država članica klauzulom o imenovanju prevoznika Zajednice, čime su omogućena ista prava pružanja vazduhoplovnih usluga svim prevoznicima Zajednice. Ugovoreno je oporezivanje goriva za vazduhoplove, kako je predviđeno Direktivom Saveta 2003/96/EZ i prevaziđene su neusklađenosti između postojećih bilateralnih sporazuma o vazdušnim uslugama i Uredbe Saveta br. 2409/92 kojom se sprečava liderstvo prevoznika treće zemlje u smislu cena vazdušnog prevoza širom Zajednice.

Ubrzo nakon potpisivanja horizontalnog sporazuma, Srbija je zajedno sa drugim zemljama Zapadnog Balkana potpisala Sporazum o ECAA u Luksemburgu, 29. juna 2006. ${ }^{37}$ Nakon pristupanja Bugarske, Rumunije i Hrvatske EU, i razdruživanja državne zajednice Srbije i Crne Gore na dve suverene i nezavisne države, Sporazum o ECAA brojao je šest pridruženih strana sa Balkana. Narodna skupština Srbije je ratifikovala ovaj Sporazum 13. maja 2009, a stupio je na snagu 1. decembra $2017 .^{38}$

\section{5) SPORAZUM O ECAA}

U skladu sa članom 1 Sporazuma o ECAA, cilj je formiranje ECAA koje se zasniva na slobodnom pristupu tržištu, slobodi osnivanja preduzeća, jednakim uslovima konkurencije i zajedničkim pravilima u oblasti sigurnosti, bezbednosti, upravljanja vazdušnim saobraćajem, socijalnih pitanja i zaštite životne sredine. Međutim, da bi Srbija postigla cilj Sporazuma u obavezi je da propise koji odgovaraju bilo kojoj predviđenoj uredbi EZ u potpunosti implementira tako da budu deo nacionalnog

\footnotetext{
${ }^{36}$ „Sporazum između Evropske zajednice i Srbije i Crne Gore o određenim aspektima vazdušnih usluga", 22.06.2006, https://ec.europa.eu/world/agreements/downloadFile.do?fullText= yes\&treatyTransId=2441, pristupljeno: 22.12 .2020 .

37 "Decision of the Council and of the Representatives of the Member States of the European Union meeting within the Council of 9 June 2006 on the signature and provisional application of the Multilateral Agreement between the European Community and its Member States, the Republic of Albania, Bosnia and Herzegovina, the Republic of Bulgaria, the Republic of Croatia, the former Yugoslav Republic of Macedonia, the Republic of Iceland, the Republic of Montenegro, the Kingdom of Norway, Romania, the Republic of Serbia and the United Nations Interim Administration Mission in Kosovo on the Establishment of a European Common Aviation Area (ECAA)", https://eur-lex.europa.eu/legal-content/EN/TXT/?uri=0J:JOL_2006 _285_R_0001_01, pristupljeno: 20.12.2020.

${ }^{38}$ International Aviation, https://ec.europa.eu/transport/modes/air/international_aviation/ country_index/ecaa_en, pristupljeno: 22.12.2020.
} 
pravnog poretka, kao i da propise koji odgovaraju direktivama EZ prenese u svoj pravni sistem na način i u obliku po izboru nadležnih organa. ${ }^{39}$

EU je predvidela da se ECAA formira sa zemljama Zapadnog Balkana u tri faze. U prvoj fazi treća i četvrta sloboda vazdušnog saobraćaja se potpuno liberalizuju. Liberalizacija pete slobode, kojom bi se omogućilo avio-kompanijama da prevoze putnike iz druge zemlje u kojoj avio-kompanija ima stanicu na svojoj liniji do destinacije u trećoj zemlji, predviđena je za drugu fazu. Treća faza obuhvata liberalizaciju preostalih sloboda i potpuni prenos vazduhoplovne pravne tekovine EU u zakonodavstva država pridruženih strana. ${ }^{40}$

Multilateralni deo Sporazuma sastoji se od Glavnog sporazuma i četiri aneksa, od kojih Aneks I sadrži spisak propisa koji su relevantni za pristupanje ECAA. Drugi deo Sporazuma čini Aneks V, koji sadrži devet protokola (tranzicionih aranžmana) koji su zapravo bilateralni sporazumi između EZ i svake pridružene strane ponaosob i sadrže uslove koje svaka pridružena strana mora da ispuni u svakom tranzicionom periodu. ${ }^{41}$

Tranzicioni aranžmani koji se odnose na našu državu predviđeni su Protokolom VI, prema kome je Srbija obavezna da do kraja prvog tranzicionog perioda ispuni određene uslove, kao na primer: a) implementacija zakonskih propisa koji se odnose na vazduhoplovnu sigurnost i bezbednost koji su predviđeni Aneksom I u domaće zakonodavstvo; b) primena Dokumenta 30 ECAA i više Uredbi kojima se regulišu: komercijalno poslovanje avio-prevoznika, pružanje zemaljskih usluga, odgovornosti i postupanja u slučaju incidenta ili udesa; c) razdvajanje pružaoca usluga vazdušnog saobraćaja i regulatornog tela, uspostavljanje nadzornog tela za službe kontrole letenja, započinjanje reorganizacije vazdušnog prostora $\mathrm{u}$ funkcionalni blok ili blokove i primena fleksibilne upotrebe vazdušnog prostora; d) ratifikovanje Montrealske konvencije; e) ostvarivanje napretka u implementaciji predviđenih pravila o državnoj pomoći i konkurenciji. ${ }^{42}$ Navedenim Protokolom naša država je takođe preuzela obavezu da će tokom drugog tranzicionog perioda primeniti sve propise koji su predviđeni Aneksom I.

Protokolom VI takođe je predviđeno i da se avio-prevoznicima Zajedince, kao i onima koji su dobili dozvolu od Srbije, dozvoljava da koriste neograničena

\footnotetext{
${ }^{39}$ Multilateralni sporazum između Evropske zajednice i njenih država članica, Republike Albanije, Bosne i Hercegovine, Republike Bugarske, Republike Hrvatske, Bivše Jugoslovenske Republike Makedonije, Republike Island, Republike Crne Gore, Kraljevine Norveške, Rumunije, Republike Srbije i Misije privremene uprave Ujedinjenih nacija na Kosovu o uspostavljanju zajedničkog evropskog vazduhoplovnog područja, članovi 1 i 3 Glavnog sporazuma.

${ }^{40}$ Ibid., čl. 29, 4.

${ }^{41}$ Ibid., članovi 1 i 3 Glavnog sporazuma i Aneks I.

${ }^{42}$ Ibid., čl. 40 Protokol VI.
} 
saobraćajna prava između bilo koje tačke u Srbiji i bilo koje tačke u državama članicama. Tek nakon prelaska u drugi tranzicioni period, avio-prevozioci Zajednice dobiće neograničena prava za obavljanje saobraćaja između tačaka u Srbiji i ostalih pridruženih strana, a avio-prevozioci koji imaju dozvolu od Srbije moći će da koriste neograničena saobraćajna prava između tačaka u različitim državama članicama.

Po pitanju slobode osnivanja preduzeća, koja je jedan od glavnih ciljeva Sporazuma, predviđeno je da se ovo pravo neće primenjivati do kraja drugog tranzicionog perioda. ${ }^{43}$ Sa druge strane, činjenica je da nacionalni avio-prevoznik Srbije koristi prava osnivanja predstavništava i ispostava za obavljanje poslova prodaje na osnovu bilateralnih ugovora koji su na snazi duže od pola veka. ${ }^{44}$

\section{6) USKLAĐIVANJE DOMAĆEG ZAKONODAVSTVA SA EVROPSKIM PROPISIMA SADRŽANIM U ANEKSU I SPORAZUMA O ESAA}

Zakoni EU dolaze u obliku uredbi, koje su pravno obavezujuće za sve države članice, i direktiva koje predstavljaju opšte principe koji se prenose u nacionalne pravne okvire. U Srbiji, evropski propisi koji se odnose na vazdušni saobraćaj se ne primenjuju direktno, već se transponuju u nacionalni pravni okvir na osnovu obaveza koje proističu iz Sporazuma o ECAA ${ }^{45}$ Na ovaj način, Srbija se pridružuje Evropskoj zajednici stvarajući jednake uslove za poslovanje avio-prevoznika Zajednice, kao i avio-prevoznika koji imaju sedište na teritoriji strane potpisnice Sporazuma i koji su operativnu dozvolu pribavili na osnovu Uredbe (EZ) br. 1008/2008, ili koji umesto operativne dozvole imaju njen ekvivalent. ${ }^{46}$ Od ratifikovanja Sporazuma o ECAA do danas, Srbija je donela više zakona i brojne podzakonske akte na osnovu kojih se izjednačavaju različiti aspekti obavljanja vazdušnog saobraćaja iznad teritorije Srbije sa evropskim praksama i regulativama. Pri tome, propisi EU u oblasti vazduhoplovstva se često menjaju, pa se neretko dešava da se i tek doneti podzakonski akti u Srbiji menjaju ili dopunjuju. ${ }^{47}$

${ }^{43}$ Ibid., članovi 7 i 8 Glavnog sporazuma i član 3, stav 3, Tranzicionih aranžmana.

44 "Agreement between the Austrian Federal Government and the Federal Executive Council of the Assembly of the Socialist Federal Republic of Yugoslavia Supplementing the Air Services Agreement between the Republic of Austria and the Federal People's Republic of Yugoslavia", signed on the $11^{\text {th }}$ of November 1953.

45 „Zaključak o usvajanju nacionalnog programa bezbednosti u civilnom vazduhoplovstvu”, Službeni glasnik RS, br. 38/2016, 1.1.4.

${ }^{46}$ „Pravilnik o operativnoj dozvoli i zajedničkim pravilima za obavljanje javnog avio-pravoza”, Službeni glasnik RS br. 54 od 29. maja 2012, i br. 76 od 29. avgusta 2013.

${ }^{47}$ Primer: Pravilnikom o inspekciji Komisije u oblasti zaštite u civilnom vazduhoplovstvu („Službeni glasnik RS”, broj 14/10) stavljen je van snage zbog stavljanja van snage Uredbe 
Nacionalni Zakon o vazdušnom saobraćaju iz 1998, koji su institucije EU smatrale neusaglašenim sa standardima EU, u potpunosti je prevaziđen stupanjem na snagu novog Zakona o vazdušnom saobraćaju $2010{ }^{48} \mathrm{U}$ poslednjih deset godina navedeni Zakon pretrpeo je više izmena i dopuna usled daljeg usklađivanja istog sa međunarodnim standardima, preporučenom praksom Međunarodne organizacije civilnog vazduhoplovstva (ICAO) i pravnim tekovinama EU. ${ }^{49}$ Određene odredbe Zakona iz 2010. prestale su da važe i stupanjem na snagu Zakona o istraživanju nesreća u vazdušnom, železničkom i vodnom saobraćaju, ${ }^{50}$ donetog, pored ostalog, i s ciljem unošenja u domaće zakonodavstvo Uredbe EU br. 996/2010 o istragama i sprečavanju nesreća i nezgoda u civilnom vazduhoplovstvu. ${ }^{51}$

Zakon o vazdušnom saobraćaju načelno obuhvata osnovne principe sadržane u evropskim uredbama i direktivama, i predviđa osnov za donošenje podzakonskih akata koji će u potpunosti preuzeti uredbe EU i primeniti direktive EU. ${ }^{52} \mathrm{U}$ tom cilju, od posebnog je značaja odredba člana 265 pomenutog Zakona kojom je predviđeno da, pored drugih propisa za čije je donošenje ovlašćen, Direktorat civilnog vazduhoplovstva Republike Srbije (DCV) donosi i propise iz oblasti vazduhoplovstva koji su sadržani u Aneksu I Sporazuma o ECAA. ${ }^{53}$

Shodno navedenom, DCV je doneo brojne pravilnike implementirajući ključne evropske propise koji regulišu sve aspekte obavljanja vazdušnog saobraćaja i koji su grupisani pod sledećim naslovima: pristup tržištu i razna pitanja; upravljanje vazdušnim saobraćajem; vazduhoplovna sigurnost; vazduhoplovna bezbednost; životna sredina; socijalni aspekti; zaštita korisnika; ostali propisi. U daljem radu prikazano je usklađivanje domaćeg zakonodavstva u određenim oblastima.

1486/2003. Umesto navedenog Pravilnika donet je Pravilnik o inspekciji Komisije u oblasti obezbeđivanja u civilnom vazduhoplovstvu („Službeni glasnik RS”, broj 19/11), kojim je preuzeta Uredba Komisije (EU) br. 72/2010 od 26. januara 2010. o sprovođenju inspekcije u oblasti obezbeđivanja u vazduhoplovstvu.

${ }^{48}$ Zakon o vazdušnom saobraćaju”, Službeni glasnik RS, br. 73/2010 од 12.10.2010.

49 „Zakon o izmenama i dopunama Zakona o vazdušnom saobraćaju”, Službeni glasnik RS br. 83/2018 i „Zakon o izmenama i dopunama Zakona o vazdušnom saobraćaju”, Službeni glasnik $R S$ br. $9 / 2020$.

50 „Zakon o vazdušnom saobraćaju”, Pravno informacioni sistem, 0 aktu, Napomena izdavača, dostupno na: https://www.pravno-informacioni-sistem.rs/SlGlasnikPortal/eli/rep/sgrs/ skupstina/zakon/2010/73/4/reg, pristupljeno: 22.12.2020.

51 „Zakon o istraživanju nesreća u vazdušnom, železničkom i vodenom soabraćaju”, Službeni glasnik RS, br. 66 od 27. jula 2015, i br. 83 od 29. oktobra 2018, Obrazloženje II.

52 „Zakon o vazdušnom saobraćaju”, Službeni glasnik RS, br. 73/2010, 57/2011, 93/2012, 45/2015, 66/2015 - dr. Zakon, 83/2018 i 9/2020.

53 „Nacionalni program za usvajanje pravnih tekovina Evropske unije”, Ministarstvo za evropske integracije, treća revizija, februar 2018, str. 668. 


\subsection{PRISTUP TRŽIŠTU I RAZNA PITANJA}

Po pitanju pristupa tržištu, Aneksom I Sporazuma o ECAA predviđeno je prihvatanje tri od pet uredbi trećeg paketa mera liberalizacije iz 1992, kao i uredbi koje se odnose na zemaljsko opsluživanje, dodelu slotova i zahteve za osiguranje za avio-prevoznike i korisnike vazduhoplova.

U skladu sa Protokolom VI, Sporazuma o ECAA, Srbija se obavezala da će u prvoj fazi pristupa implementirati jednu (Uredbu br. 2409/92) od tri uredbe trećeg paketa mera liberalizacije iz 1992. predviđenih Aneksom I, koja se odnosi na slobodu određivanja tarifa vazdušnih usluga, kao i Uredbu br. 96/67 kojom je liberalizovano tržište zemaljskih usluga. Uredbe br. 785/2004 i br. 95/93 kojima se regulišu dodela slotova i osiguranje ostaju obaveza koju Srbija treba da ispuni tokom druge faze pristupanja ECAA.

Tri uredbe trećeg paketa mera za liberalizaciju (br. 2407/92, 2408/92 i 2409/92) predviđene Aneksom I Sporazuma o ECAA, kao uslov za pristupanje Srbije tržištu ECAA, prestale su da važe u novembru 2008. stupanjem na snagu Uredbe (EZ) br. 1008. Na osnovu ove Uredbe iz 2008. (sa amandmanima iz 2018. i 2019), ${ }^{54}$ predviđeno je da ako kompanija ispunjava uslove kao što su profesionalne i tehničke sposobnosti, finansijska mogućnost i organizacija kojima je zagarantovana sigurnost obavljanja saobraćaja, kompanija će dobiti operativnu dozvolu ${ }^{55}$ država članica kako bi mogla da pruža usluge vazdušnog prevoza na tržištu EU, bez diskriminacije na osnovu nacionalnosti.

U cilju ispunjenja ugovornih obaveza predviđenih za prvi tranzicioni period za pristup tržištu ECAA, DCV je doneo Pravilnik o operativnoj dozvoli i zajedničkim pravilima za obavljanje javnog avio-prevoza $2013 .{ }^{56} \mathrm{Na}$ osnovu ovog Pravilnika, delimično su implementirana zajednička pravila za obavljanje avio-prevoza u Zajednici predviđena Uredbom 1008/2008. Usvojeni su pojedini članovi ove Uredbe koji su predviđeni kao obaveza Srbije za prvi tranzicioni period, a kojima su regulisane definicije pojedinih termina koji se redovno koriste u vazduhoplovnom pravu EU, kao i pravila koja se odnose na slobodu određivanja cene prevoza, obaveštavanje i nediskriminaciju u vezi sa cenama prevoza ili tarifa, poreza,

\footnotetext{
54 „Uredba Evropskog Parlamenta i Saveta br. 1008/2008/E3 o opštim pravilima za obavljanje usluga vazdušnog pravoza u Zajednici", 24. septembar 2008, OJ L 293.

${ }^{55}$ Ibid., član 4.

${ }^{56}$ „Pravilnik o operativnoj dozvoli i zajedničkim pravilima za obavljanje javnog avio-prevoza”, Službeni glasnik $R S$ br. 54/12 i 76/13. Pravilnik je prvi put usvojen sredinom 2012. Revidiran je 2013. zbog brisanja člana 5 kojim je bio propisan prestanak važenja Pravilnika o određivanju cena u javnom avio-prevozu unutar Zajednice i članova 3 do 12 Pravilnika o uslovima i postupku izdavanja uverenja o osposobljenosti za obavljanje javnog avio-transporta čime je izražena namera donosioca da se ti propisi i dalje primenjuju.
} 
aerodromskih naknada i kazni u slučaju povrede ovih pravila. Takođe, usvojen je propis iz Završnih odredbi Uredbe 1008/2008 u vezi sa saradnjom i pravom Komisije na pribavljanje podataka radi izvršavanja svojih obaveza iz ove Uredbe. ${ }^{57}$

Drugi zajednički propisi predviđeni Uredbom 1008/2008 na osnovu kojih su regulisani pravo i obaveze prevoznika Zajednice za izdavanje i korišćenje operativne dozvole, pristup linijama u Zajednici, i drugi komercijalni aspekti bitni za poslovanje avio-prevoznika na tržištu Zajednice, ostaju rezervisani za prevoznike Zajednice.

Opsluživanje vazduhoplova i putnika na zemlji bilo je povereno aerodromskim vlastima i avio-kompanijama koje obavljaju saobraćaj na odnosnim aerodromima sve do kraja XX veka. U skladu sa postepenim uvođenjem zajedničke evropske politike vazdušnog saobraćaja, Savet je usvojio 1996. Direktivu 96/67/EZ, ${ }^{58}$ otvorivši tržište usluga opsluživanja putnika i vazduhoplova na zemlji u državama članicama EU. Na osnovu ove Direktive države članice su uvele različite tipove liberalizacije. ${ }^{59}$ Sada, zemaljske usluge na aerodromima u Evropi pružaju aerodromske kompanije za zemaljske usluge, avio-kompanije koje same obavljaju ovakve poslove na aerodromima, nezavisne kompanije za pružanje zemaljskih usluga i avio- kompanije kao treća lica koja pružaju usluge zemaljskog opsluživanja.

U cilju liberalizacije tržišta zemaljskih usluga u Srbiji i usklađivanja zakonskih propisa Srbije sa Direktivom Saveta 96/67/EEZ, DCV je prvo doneo Pravilnik o pristupu tržištu usluga zemaljskog opsluživanja na aerodromima tokom 2013, a zatim Pravilnik o pružanju usluga zemaljskog opsluživanja na aerodromima sredinom 2015, ${ }^{60}$ kojim je preuzeta Direktiva Saveta 96/67/EZ. Na ovaj način, uređeno je da na srpskim aerodromima koji se koriste za javni avio-prevoz sa godišnjim prometom većim od 2.000 .000 putnika ili 50.000T robe, pružaoci usluga zemaljskog opsluživanja imaju slobodan pristup tržištu radi pružanja jedne ili više usluga, uz uslov da imaju sedište na teritoriji Srbije. ${ }^{61}$ Svaki korisnik aerodroma može da se samoopslužuje ili da izabere pružaoca usluga zemaljskog opsluživanja, uz uslov da na pojedinim aerodromima DCV može da ograniči pravo na samoopsluživanje na najmanje dva korisnika aerodroma. ${ }^{62}$

${ }^{57}$ Ibid., prilog, član 2, stavovi 7, 10, 11, 13, 14, 18 i 19.

${ }_{58}$ „Direktiva Saveta 96/67/EZ od 15. oktobra 1996. o pristupu tržištu usluga zemaljskog opsluživanja na aerodromima Zajednice", OJ L 272.

59 "Study on the Impact of Directive 96/67/EC on Ground Handling Services 1996-2007", Airport Research Center, Final Report, February 2009, https://ec.europa.eu/transport/sites/transport /files/modes/air/studies/doc/airports/2009_02_ground_handling.pdfpristupljeno: 12.12.2020.

${ }^{60}$ „Pravilnik o pružanju usluga zemaljskog opsluživanja na aerodromima”, Službeni glasnik RS, br. 61 od 10. jula 2015.

${ }^{61}$ Ibid., član 6.

${ }^{62}$ Ibid., član 7. 
Slot je u EU definisan kao dozvola koju daje koordinator za korišćenje punog obima aerodromske infrastrukture neophodne za obavljanje saobraćaja na aerodromu određenog dana i u određeno vreme za sletanje. ${ }^{63} \mathrm{U}$ cilju regulisanja dodele slotova, EU je 1995. usvojila zajednička pravila za dodelu slotova na aerodromima Zajednice. Na preopterećenim aerodromima slotovi se dodeljuju avio-kompanijama na pravičan, nediskriminatorni i transparentan način od strane nezavisnog koordinatora slotova. ${ }^{64} \mathrm{EU}$ sprovodi dalje reforme kako bi se omogućio pristup novim avio-kompanijama koje ulaze na tržište, normalno odvijanje saobraćaja na aerodromima sa velikom gustinom saobraćaja, i kako bi se ojačali propisi o nezavisnosti koordinatora i povećao nivo transparentnosti transakcija u vezi sa slotovima. Tako, Uredba EZ br. 95/93 o opštim pravilima za dodelu slotova na aerodromima Zajednice je izmenjena Uredbama br. 894/2002/EZ ${ }^{65}$ i 793/2004/EZ . ${ }^{66}$ Od 2004. godine Komisija razmatra kako da se razvijaju tržišno orijentisani mehanizmi za olakšavanje prenosa slotova i efikasnije korišćenje oskudnih aerodromskih kapaciteta, održi efikasna konkurencija na aerodromima Zajednice i da se osigura da bilo koja šema za dodelu alternativnih slotova bude od koristi sveobuhvatnoj transportnoj politici EU i ne bude u sukobu sa ostalim postupcima za dodelu slotova širom sveta. ${ }^{67}$

U cilju usklađivanja sa evropskim propisima za dodelu slotova, Srbija je 2014. donela Pravilnik o zajedničkim pravilima za dodelu slotova i usklađivanju redova letenja na aerodromima kako bi uskladila propise sa nizom uredbi EU donetih u periodu od 1995. do 2009, koje regulišu pitanje dodele slotova. ${ }^{68}$

\subsection{VAZDUHOPLOVNA BEZBEDNOST}

Od januara 2003. pitanje bezbednosti na svim aerodromima EU bilo je regulisano Uredbom (EZ) br. 2320/2002. ${ }^{69}$ Ova Uredba doneta je nakon terorističkih

63 „Uredba Evropskog parlamenta i Saveta br. 793/2004/EZ od 21. aprila 2004. o izmeni Uredbe Saveta br. 95/93/EEZ o opštim pravilima za dodelu slotova na aerodromima Zajednice", OJ L 138.

${ }^{64}$ „Uredba Saveta br. 95/93 EEZ o opštim pravilima za dodelu slotova na aerodromima Zajednice", OJ L 014, 18.01.1993.

65 „Uredba Evropskog parlamenta i Saveta (EEZ)”, br. 894/2002 od 27. maja 2002.

${ }^{66}$ „Uredba Evropskog parlamenta i Saveta br. 793/2004/EZ od 21. aprila 2004. o izmeni Uredbe Saveta br. 95/93/EEZ o opštim pravilima za dodelu slotova na aerodromima Zajednice", OJ L 138.

67 "Study to Assess the Effects of Different Slot Allocation Schemes: A Final Report for the European Commission", 22, 204 (2004).

68 „Pravilnik o zajedničkim pravilima za dodelu slotova i usklađivanju redova letenja na aerodromima", Službeni glasnik RS, br. 10 od 31. januara 2014.

69 „Uredba (EZ) br. 230/2002 Evropskog parlamenta i Saveta o uspostavljanju zajedničkih pravila u oblasti obezbeđivanja u civilnom vazduhoplovstvu", 16. decembar 2002, oJ L 355/1. 
napada u SAD septembra 2001, na osnovu standarda sadržanim u ICAO Aneksu 17 i preporuka Evropske konferencije o civilnom vazduhoplovstvu, kako bi se uspostavila zajednička pravila za zaštitu osoba i dobara od radnji nezakonitog ometanja koje ugrožavaju civilno vazduhoplovstvo. Šest godina kasnije, Uredba (EZ) br. 2320/2002 zamenjena je Uredbom br. 300/2008 kako bi se odgovorilo na narastajuće rizike i omogućilo uvođenje novih tehnologija. ${ }^{70}$ Dužnost svake države članice jeste da: uspostavi program nacionalne bezbednosti u civilnom vazduhoplovstvu, odredi jedinstveno telo odgovorno za koordinaciju i nadzor sprovođenja bezbednosnih standarda i nacionalni program kontrole kvaliteta i bezbednosti civilnog vazduhoplovstva.

U cilju uređenja zajedničkih pravila za obezbeđivanje civilnog vazduhoplovstva i usaglašavanja sa procedurama i standardima Zajedince, Republika Srbija je preduzela brojne korake. Pre svega, DCV je doneo Pravilnik o zajedničkim pravilima u oblasti obezbeđivanja u civilnom vazduhoplovstvu 2011, kojim su, uz prilagođavanje pravu Republike Srbije, preuzeta prava predviđena Uredbom (EZ) br. 300/2008, uključujući i obavezu donošenja Nacionalnog programa za obezbeđivanje u vazduhoplovstvu i Nacionalnog programa za kontrolu kvaliteta mera obezbeđivanja u vazduhoplovstvu. ${ }^{71}$

Takođe, navedena krovna institucija donela je i više drugih pravilnika i programa, ${ }^{72}$ obezbeđujući poštovanje člana 12 Sporazuma o ECAA, kojim je predviđena obaveza strana ugovornica da se zajednički osnovni standardi i mehanizmi u pogledu vazduhoplovne bezbednosti, sadržani u Aneksu I, primenjuju na svakom aerodromu koji se nalazi na njihovim teritorijama.

Tokom implementacije evropskih propisa donošenjem različitih pravilnika i programa, sve navedene uredbe koje se odnose na vazduhoplovnu bezbednost predviđene Aneksom I Sporazuma o ECAA, stavljene su van snage i donete su nove uredbe. Zato, DCV je više puta menjao i dopunjavao donete pravilnike, i stavljao van snage donete pravilnike donošenjem novih pravilnika kako bi se obezbedila usaglašenost sa novodonetim uredbama EU u oblasti vazduhoplovne bezbednosti. ${ }^{73}$

70 "Mobility and Transport, Aviation Security Policy", European Commission, (https://ec.europa. eu/transport/modes/air/security/aviation-security-policy_en, pristupljeno: 12.12.2020.

71 „Pravilnik o zajedničkim pravilima u oblasti obezbeđivanja u civilnom vazduhoplovstvu”, Službeni glasnik RS broj 2 od 18. januara 2011, članovi 10 i 11.

${ }^{72}$ Zvanični sajt Direktorata civilnog Vazduhoplovstva Republike Srbije, Implementacija evropskih propisa sadržanih u Aneksu I ESAA Sporazuma u domaće zakonodavstvo, str. 13-15.

${ }^{73}$ Zvanična veb stranica DCV. Na primer, Uredba br. 820/2008 od 8. avgusta 2008. stavljena je van snage donošenjem Uredbe br. 185/2010 o utvrđivanju detaljnih mera za primenu zajedničkih osnovnih standarda u vazduhoplovnoj bezbednosti. Uredba br. 185/2010 dopunjavana je i menjana dvadesetak puta u periodu od stupanja na snagu do 2015. i stavljena van snage Sprovedbenom uredbom Komisije (EU) br. 2015/1998, koja je dalje izmenjena i 


\subsection{ZAŠTITA KORISNIKA}

EU je razvila značajan zakonodavni okvir za zaštitu prava putnika u avioprevozu. Opšti princip koji stoji u osnovi propisa EU za zaštitu korisnika usluga aviosaobraćaja jeste pravilo da su avio-kompanije dužne da brinu o svojim putnicima.

Propisane mere uključuju obeštećenje putnika, zaštitu privatnosti podataka, pomoć za putnike sa smanjenom pokretljivošću i pravo putnika da budu informisani o prevozniku. Obim i primena propisa EU variraju u zavisnosti od faktora kao što su reciprocitet, mesto kupovine karte, aerodrom polaska i postojanje odnosnih regulativa u zakonodavstvima država koje nisu članice EU.

Osnovni propisi kojima se regulišu prava putnika u vazdušnom prevozu unutar EU i vazdušnom prevozu putnika kojima je krajnja destinacija na teritoriji EU jesu: Uredba (EZ) br. 261/2004, ${ }^{74}$ Uredba (EZ) br. 2111/2005, ${ }^{75}$ i Uredba br. 1107/2006. ${ }^{76}$

Opšti utisak jeste da je zaštita putnika doživela veliki pomak usvajanjem Uredbe (EZ) br. 261/2004 o uspostavljanju zajedničkih prava putnika u slučaju uskraćivanja ukrcaja, otkazivanja i dužeg kašnjenja leta. Međutim, postoje brojne kontroverze i rasprave u vezi sa istom. Ova Uredba je brzo postala predmet brojnih sudskih sporova, pri čemu se nacionalni sudovi država članica često obraćaju Sudu EU sa zahtevima za tumačenje pravnih nejasnoća u vezi sa pojedinim odredbama. ${ }^{77}$

dopunjena Sprovedbenom uredbom Komisije (EU) br. 2015/2426 od 18. decembra 2015, o izmeni i dopuni Uredbe (EU) br. 2015/1998 u pogledu trećih zemalja za koje se priznaje da primenjuju standarde obezbeđivanja ekvivalentne osnovnim standardima obezbeđivanja u vazduhoplovstvu i Sprovedbenom uredbom Komisije (EU) br. 2017/815 od 12. maja 2017. o izmeni i dopuni Uredbe (EU) br. 2015/1998 u pogledu pojašnjenja, usklađivanja i pojednostavljenja određenih mera obezbeđivanja u vazduhoplovstvu. U cilju preuzimanje ovih propisa EU, DCV je prvo doneo Pravilnik o detaljnim merama za primenu zajedničkih osnovnih standarda obezbeđivanja u vazduhoplovstvu 2011, koji je izmenjen i dopunjen 2014, a zatim stavljen van snage donošenjem novog Pravilnika o detaljnim merama za primenu zajedničkih osnovnih standarda obezbeđivanja u vazduhoplovstvu početkom 2018.

74 „Uredba Evropskog parlamenta i Saveta br. 261/2004 od 11. februara 2004. o utvrđivanju opštih pravila odštete i pomoći putnicima u slučaju uskraćenog ukrcavanja, otkazivanja leta i dužeg kašnjenja leta u polasku", OJ L 046.

75 „Uredba (EZ) br. 2111/2005 Evropskog parlamenta i Saveta od 14. decembra 2005”; “Regulation (EC) No 2111/2005 of the European Parliament and of the Council of 14 December 2005 on the establishment of a Community list of air carriers subject to an operating ban within the Community and on informing air transport passengers of the identity of the operating air carrier, and repealing Article 9 of Directive 2004/36/EC" (Text with EEA relevance).

${ }^{76}$ „Uredba (EZ) br. 1107/2006 Evropskog parlamenta i Saveta od 5. jula 2006. o pravima osoba sa invaliditetom i osoba sa smanjenom pokretljivošću u vazdušnom prevozu", OJ L 204.

${ }^{77}$ Air Passenger Rights, European Case Law, January 2019, https://ec.europa.eu/transport / sites/transport/files/2019-summary-of-the-most-relevant-cjeu-judgements.pdf, pristupljeno: 12.12.2020. 
S ciljem da se obezbedi da putnici budu u potpunosti informisani o identitetu prevoznika u trenutku rezervacije, EU je donela Uredbu (EZ) br. 2111/2005. Ovom Uredbom uspostavljena je lista avio-prevoznika kojima je zabranjeno obavljanje saobraćaja širom Zajednice koja se naziva crnom listom EU. Uredba takođe uspostavlja zajedničke kriterijume za zabranu rada odnosnih prevoznika i zahteva da države obaveste Komisiju o bilo kojoj zabrani koju uspostave. Nova pravila se primenjuju na sve letove (uključujući letove između dve zemlje koje nisu članice EU) koji su deo ugovora o prevozu koji započinje u EU.

Sredinom 2006. godine EU je usvojila Uredbu br. 1107/2006 o pravima lica sa invaliditetom i lica sa smanjenom pokretljivošću u avio-prevozu. Nova pravila se primenjuju na sve putnike sa invaliditetom i smanjenom pokretljivošću koji putuju vazdušnim putem, a polaze sa aerodroma ili tranzitiraju kroz aerodrome koji se nalaze na teritoriji države članice.

$\mathrm{U}$ cilju usklađivanja nacionalnih zakona koji regulišu prava putnika $\mathrm{u}$ vazdušnom saobraćaju sa odredbama Uredbe (EZ) br. 261/2004 i Uredbe (EZ) br. 1107/2006, Narodna skupština Srbije donela je Zakon o obligacionim i osnovama svojinsko-pravnih odnosa u vazdušnom saobraćaju. ${ }^{78}$ Prava garantovana ovim Zakonom primenjuju se na: putnike koji putuju sa aerodroma koji se nalazi na teritoriji strane potpisnice ESAA sporazuma na koju se Sporazum o ESAA primenjuje, kao i na putnike koji putuju sa aerodroma u trećoj državi na aerodrom koji se nalazi unutar ESAA područja.

Takođe, Srbija je obezbedila primenu pravila predviđenih Uredbom (EZ) br. 2111/2005 donošenjem Pravilnika o bezbednosnom pregledu stranih vazduhoplova na platformi aerodroma, ${ }^{79}$ akta koji je donet na osnovu Liste avioprevoznika kojima je zabranjeno ili ograničeno letenje u EU. Početkom 2020. stupio je na snagu i Pravilnik o zabrani ili ograničenju letenja avio-prevozilaca iz trećih država ${ }^{80}$ na osnovu kog su uređeni uslovi pod kojima se avio-prevoziocima iz trećih država, iz razloga bezbednosti, zabranjuje ili ograničava letenje u EU i Republici Srbiji, uspostavljaju, objavljuju i ažuriraju liste avio-prevozilaca kojima je zabranjeno ili ograničeno letenje u EU i Srbiji, kao i način obaveštavanja putnika u avio-prevozu o identitetu stvarnog avio-prevozioca na njihovom letu.

\section{4. ŽIVOTNA SREDINA}

Stav EU jeste da održivost razvoja transportnog sistema zavisi od integrisanog pristupa zaštiti životne sredine. EU veruje da održiv razvoj vazdušnog transporta

78 „Zakon o obligacionim i osnovama svojinsko-pravnih odnosa u vazdušnom saobraćaju”, Službeni glasnik RS, br. 87/11 i 66/15.

79 „Pravilnik o bezbednosnom pregledu stranih vazduhoplova na platformi aerodroma”, Službeni glasnik $R S$, br. 2/11.

${ }^{80}$ „Pravilnik o zabrani ili ograničenju letenja avio-prevozilaca iz trećih država”, Službeni glasnik $R S$, br. 1 od 10.01.2020. 
zavisi od poboljšanja tehničkih standarda o buci i emisiji gasova i od uvođenja ekonomskih podsticaja radi uticaja na tržište. ${ }^{81} \mathrm{U}$ svojoj Beloj knjizi o evropskoj transportnoj politici, Evropska komisija je naglasila uvođenje mera za ograničenje nivoa buke i emisije gasova kao neophodan uslov za postizanje ravnoteže između rasta vazdušnog transporta i zaštite životne sredine. ${ }^{82}$

U martu 2002. stupila je na snagu Direktiva br. 2002/30 o uspostavljanju pravila i procedura u pogledu uvođenja operativnih ograničenja u vezi sa bukom na aerodromima Zajednice. ${ }^{83}$ Od prevoznika se zahtevalo da smanje kretanje marginalno usklađenih vazduhoplova na određenim aerodromima za $20 \%$ godišnje. Međutim, aerodromske vlasti su iskazale nezadovoljstvo ovom direktivom, smatrajući da nije imala direktnog uticaja na upravljanje bukom na aerodromima i da je predviđala ono što je već bilo uređeno nacionalnim zakonima ${ }^{84}$ Direktiva 2002/30 prestaje da važi sredinom 2016. na osnovu odredbe iz Uredbe br. $589 / 2014$ o uspostavljanju pravila i procedura u pogledu uvođenja operativnih ograničenja u vezi sa bukom na aerodromima Zajednice.

Kao deo politike Zajednice za postizanje visokog nivoa zaštite zdravlja i zaštite životne sredine, doneta je Direktiva EZ 2002/49 o proceni i upravljanju bukom u životnoj sredini. ${ }^{85}$ Direktivom je uspostavljen zajednički pristup praćenju i upravljanju bukom u životnoj sredini, uključujući upotrebu zajedničkih metoda procene i zajedničkih pokazatelja buke. Ciljevi Direktive su da se izbegnu, spreče ili smanje prioritetno štetni efekti, uključujući uznemirenost, usled rasta nivoa buke u životnoj sredini.

Obe navedene direktive predviđene su, pored ostalih EU propisa kojima su regulisana pitanja životne sredine, kao uslov za pristupanje Srbije ECAA. Direktiva 2002/49/EZ delimično je preneta u nacionalno zakonodavstvo Zakonom o zaštiti od buke u životnoj sredini i podzakonskim aktima kao što su: Uredba o indikatorima buke, graničnim vrednostima, metodama za ocenjivanje indikatora buke, uznemiravanja i štetnih efekata buke u životnoj sredini, Pravilnik o sadržini i

\footnotetext{
81 "Air Transport and the Environment Towards Meeting the Challengesof Sustainable Development", Communication from the Commission to the Council, COM (1999) 640 final (Dec. 1, 1999).

82 "White Paper on European Transport Policy for 2010: Time to Decide", p. 39.

83 "Council Directive 2002/30/EC", 2002 OJ L 85/40, član 6.

84 "Noise Operation Restrictions at EU Airports", Report from the Commission to the Council and the European Parliament of 15 February 2008, Report on the application of Directive 2002/30/EC) (COM(2008) 66 final), p. 4.

85 "Directive 2002/49/EC of the European Parliament and of the Council of 25 June 2002 relating to the assessment and management of environmental noise", OJ L 189.
} 
metodama izrade strateških karata buke i načinu njihovog prikazivanja javnosti, ${ }^{86}$ i Pravilnikom o metodologiji za izradu akcionih planova. ${ }^{87}$

\section{ZAKLJUČAK}

Stvaranje unutrašnjeg vazduhoplovnog tržišta EU i usklađivanje nacionalnih pravnih sistema država članica u domenu vazduhoplovstva trajalo je skoro pune četiri decenije. Prihvatanje zajedničke politike vazdušnog prevoza EU bilo je otežano zbog nejasnoća u vezi sa primenljivošću pojedinih članova Rimskog ugovora na avio-prevoz, sukoba interesa i različitih zakonskih, ekonomskih i političkih težnji različitih zapadnoevropskih država, kao i važnosti brojnih bilateralnih ugovora $o$ međunarodnom avio-prevozu. Tek nakon više sudskih sporova vođenih pred ESP i nakon što je ESP pojasnio zakonodavna ovlašćenja institucija EU, dovršen je postupak liberalizacije vazdušnog saobraćaja EU i stvoreno je jedinstveno vazduhoplovno tržište EU. U osnovi politike EU za liberalizaciju vazdušnog saobraćaja stoji umanjenje državne moći u odnosu na civilno vazduhoplovstvo Zajednice i sprovođenje propisa o konkurenciji i na ovaj vid prevoza. Povećanje nivoa konkurencije dovelo je do stvaranja novih poslovnih modela, ulaska novih avio-kompanija na tržište EU, opšte konsolidacije i ekspanzije tržišta. Rast vazduhoplovnog tržišta unutar EU donela je i njenu težnju da proširi svoje poslovanje u oblasti vazduhoplovstva i izvan svojih granica, kroz pristupanje trećih zemalja Sporazumu o ECAA, uz uslov da se zakonodavstvo trećih zemalja uskladi sa pravnom tekovinom EU. Među prvima, potpisan je Sporazum o ECAA sa zemljama Zapadnog Balkana.

Integracija vazduhoplovnog tržišta $\mathrm{EU}$ dogodila se u istorijskom periodu u kome je naša zemlja bila izopštena iz međunarodne zajednice. Srbija je počela postupak pridruživanja ECAA kao deo sveobuhvatne strategije za vraćanje u međunarodne tokove pristupanjem i pridruživanjem EU. U trenutku kada je Sporazum o ECAA potpisan, srpski nacionalni prevoznik bio je iscrpljen sankcijama koje su bile nametnute našoj zemlji 1990-ih i konstantno je vodio borbu za opstanak na tržištu.

Sam proces pridruživanja ECAA odlikuju brojni uslovi koje država Srbija mora da ispuni, dugotrajni procesi implementacije evropskih propisa koji podležu čestim

\footnotetext{
${ }^{86}$ „Pravilnik o sadržini i metodama izrade strateških karata buke i načinu njihovog prikazivanja javnosti", Službeni glasnik RS 80/2010.

${ }^{87}$ Zvanični sajt Direktorata civilnog vazduhoplovstva Republike Srbije, Implementacija evropskih propisa sadržanih u Aneksu I ESAA Sporazuma u domaće zakonodavstvo, 16.
} 
izmenama i stavljanju van snage, nepostojanje bilo kakvih jasnih rokova o okončanju predviđenih faza za pridruživanje i nejasne prednosti koje multilateralni sporazum o ECAA pruža Srbiji u poređenju sa važećim sporazumima i/ili aranžmanima na osnovu bilateralnih sporazuma. Pored toga, nacionalni avioprevoznik suočen je sa izazovom da uspostavi model poslovanja koji je održiv i profitabilan na novom tržištu koje se menja sa promenom vazduhoplovnih propisa i na kome vladaju uslovi sve jače konkurencije.

Uopšteno govoreći, prva faza Sporazuma o ECAA ne pruža ništa više od slobode obavljanja vazdušnog saobraćaja koje Srbija ima i na osnovu važećih bilateralnih sporazuma. Takođe, Sporazum o ECAA zabranjuje pravo na osnivanje preduzeća do kraja drugog tranzicionog perioda. Tek ulaskom u drugu fazu, avio-prevoznicima koji imaju dozvolu od Republike Srbije bilo bi dozvoljeno da koriste neograničena saobraćajna prava između tačaka u različitim državama članicama EZ, dok bi prevoznicima Zajednice bilo dozvoljeno da koriste neograničena saobraćajna prava između tačaka u Srbiji i ostalih pridruženih strana. Iako ovo može da izgleda kao prednost koju bi Srbija dobila, slučajevi otvorenog neba koji su bili potpisani između različitih država članica $\mathrm{EU}$, s jedne strane, i SAD s druge strane, a zatim okončani nakon Odluke ESP od 5. novembra 2002, uče nas da je pravo stvaranja čvorišta na teritoriji male strane države isplativije od prava obavljanja avio-saobraćaja do bilo koje tačke širom znatno veće teritorije.

Potpisivanje ugovora o otvorenom nebu između država članica i SAD moglo je da izgleda kao da su SAD velikodušno odobrile državama članicama EU širok izbor sletanja, na bilo kojoj tački unutar svoje velike teritorije, u zamenu za geografski neravnopravan izbor sletanja u „maloj” evropskoj zemlji. Međutim, otvoreno nebo iznad Atlantika je samo američkim prevoznicima omogućilo stvaranje i kontrolu mreže ruta po modelu zvezdastog saobraćaja sa čvorištem u EU. Dok su evropski prevoznici mogli da lete do bilo koje tačke u SAD samo iz svojih zemalja, američki prevoznici su mogli da lete iz bilo koje zemlje sa kojom imaju sklopljen ugovor o otvorenom nebu do bilo koje tačke u SAD, kao i iz jedne zemlje „otvorenog neba” u drugu zemlju EU, što je zapravo oblik kabotaže unutar EU posmatrane kao jedinstveno vazduhoplovno tržište.

Srbija je ispunila veliki broj zahteva za završetak prvog tranzicionog perioda, tako da se otvara pitanje šta nas očekuje na kraju prve faze. Kao i uvek kada se sagledava sudbina naše zemlje potrebno je baciti pogled i „preko plota” kako bi steklo ispravno viđenje. Susedna Hrvatska je jedina pridružena strana koja je ispunila sve uslove za ulazak u drugu fazu. Prava predviđena za drugu fazu pridruživanja nisu joj bila priznata, a zainteresovane zemlje su pronašle alternativan način za bilateralnu privremenu primenu ECAA. Hrvatska je postala članica EU 2013, međutim, ni članstvo u EU nije donelo poslovnog uspeha hrvatskoj aviokompaniji. Domaće vazduhoplovno tržište doživelo je ekspanziju ulaskom ekonomski jačih avio-kompanija, dok je hrvatska Vlada 2019. donela odluku da 
„upumpa” 33,7 miliona evra u svoju nacionalnu avio-kompaniju kako bi je spasila od stečaja. ${ }^{88}$

Nakon svega izloženog nameću se brojna pitanja. Da li politika EU za pridruživanje ECAA i usklađivanje nacionalnih propisa sa pravnom tekovinom EU vodi ka osvajanju vazduhoplovnog tržišta zemalja Zapadnog Balkana od strane ekonomski jakih prevoznika Zajednice? S obzirom na dugotrajnost procesa, da li će srpski avio-prevoznik dočekati pridruživanje Evropskoj zajednici? Ako i dočeka, da li će biti dovoljno jak da učestuje na tržištu po novim pravilima sve jače konkurencije i u svom dvorištu? Ukoliko nacionalni prevoznik ne dočeka pridruživanje neba Srbije zajedničkom evropskom vazduhoplovnom području, kakve koristi bi imala naša država od harmonizacije nacionalnog zakonodavstva zarad poslovanja stranih prevoznika na suverenom vazdušnom prostoru iznad nacionalne teritorije? Stanovništvo zemlje čiji je nacionalni zakonodavni sistem usklađen sa pravom EU u domenu vazduhoplovstva, a pri tome nema nacionalnog avio-prevoznika, osuđeno je na gubitak direktnih linija od nacionalnog značaja i javnog interesa, dok će, s druge strane, biti prinuđeno da koristi vezne letove ili letove od čvorišta $u$ susednim državama do željenih destinacija po planovima letenja koji su najisplativiji stranim avio-prevoznicima.

\section{8) LITERATURA:}

Smithies, Richard, "Regulatory Convergence - Extending the Reach of EU Aviation Law", Journal of Air Law and Commerce, Vol 72/3, 2007.

Burghouwt, Guillaume, Airline Network Development in Europe and its Implications for Airport Planning, Ashgate Publishing, Ltd., 2007.

Study on the Impact of Directive 96/67/EC on Ground Handling Services, 19962007 Final Report, Airport Research Center, February 2009.

88 „Hrvatska vlada sa 33,7 mil. EUR spašava Croatia airlines od stečaja”, dostupno na: https://www.ekapija.com/news/2642899/hrvatska-vlada-sa-337-mil-eur-spasava-croatiaairlines-od-stecaja pristupljeno: 20.12.2020. 
Evropsko zakonodavstvo, br. 75/2021

\section{HARMONISATION OF THE LEGISLATIVE SYSTEM OF THE REPUBLIC OF SERBIA WITH THE LAW OF THE EUROPEAN UNION IN THE FIELD OF CIVIL AVIATION}

Summary: The "terms approximation" and "harmonisation" of national legal systems have been used carefully since the very beginning of the creation of the Community. The term harmonisation is a necessary precondition for harmonising the legal systems of different countries at the highest possible level. The reason for the harmonisation of legal systems lies in the basic need for the establishment or functioning of the common market, which is one of the main pillars of the Community. The legal basis for harmonisation for the EU Member States may be sought in the provisions of Articles 3 (f) and 94 of the Treaty establishing the European Community. Following the establishment of the single European aviation market and the expansion of air traffic in a liberalized market, the EU has developed a foreign aviation policy based on the accession of third countries to the European Common Aviation Area (hereinafter ECAA), provided that national legislative systems comply with EU regulations. For the Republic of Serbia, which is not a member of the EU, the harmonisation of national regulations with EU law is part of the overall strategy for joining the EU. The Stabilisation and Association Agreement entered into force on 1 September 2013, giving Serbia the status of an EU associated state. The transport policy and harmonisation of aviation laws with the acquis communautaire was provided for in Chapter 14. The two most important obligations our country has undertaken are establishing a free trade zone and harmonising legislation with EU law. The process of harmonisation of the legislative system of Serbia with the EU law in the field of civil aviation has been going on for almost 15 years through the process of accession to the ECAA. The question remains whether efforts to harmonise all aspects of air traffic will bring economic and social benefits to Serbia as well.

Key words: Single European Aviation Market, Common European Aviation Area, ECAA Agreement, air transport liberalization, harmonisation of the legislative system with EU law, implementation of European regulations contained in Annex I of the ECAA. 